\title{
NATURAL DYNAMICS OF URBAN POPULATION IN THE EASTERN CARPATHIANS IN THE POST-COMMUNIST PERIOD
}

\author{
MĂDĂLIN-SEBASTIAN LUNG', GABRIELA-ALINA MUREȘAN²
}

\begin{abstract}
Natural dynamics of urban population in the Eastern Carpathians in the post-communist period. The Eastern Carpathians represent an important group of Romanian Carpathians. 43 cities belonging to 12 counties (Bacău, Bistriţa, Braşov, Buzău, Covasna, Harghita, Maramureş, Mureş, Neamţ, Prahova, Satu Mare, Suceava) were identified in their territory. The aim of the study is to analyze the urban population natural dynamics in the Eastern Carpathians in the post-communist period (1992-2011). At the same time, we tried to identify some of the causes that led to the evolution (increase and decrease) of the values of analyzed demographic indicators. In 1992, only four cities had negative natural dynamics (natural decrease). After 1992, many of the cities began to record negative values of the natural increase. The urban area population in the Eastern Carpathians began to record higher mortality rates, at the expense of birth rates. In 2002, negative values of the natural increase were recorded in 24 administrative units. At the last census, 28 urban centers had negative values of natural increase. The indicators considered were the birth rate, the mortality rate and the rate of natural increase.
\end{abstract}

Keywords: Eastern Carpathians, cities, birth rates, mortality rates, rate of natural increase.

\section{INTRODUCTION}

The main aim of the study is to analyze the natural dynamics of the population of the cities located in the Eastern Carpathians. 43 cities are located in this group of Romanian Carpathians (fig. 1). The natural dynamics were analyzed using three demographic indicators: birth rate, mortality rate and the

\footnotetext{
${ }_{1}^{1}$ Babeş-Bolyai University, Faculty of Geography, 400006, Cluj-Napoca; email:lungmadalin@yahoo.com

2 Babeş-Bolyai University, Faculty of Geography, 400006, Cluj-Napoca; email: alina.muresan@ubbcluj.ro
} 
rate of natural increase. The three indicators were calculated for the postcommunist census years; we also analyzed the demographic evolution of urban areas. At the same time, we considered identifying possible demographic risk phenomena that may unbalance the good functionality of cities.

The population has become a research topic for several fields (geography, history, sociology). There are several geographical studies aimed at studying the population from different parts of the country (Giurcăneanu, 1988; Niță, 2007; Tănasă, 2007; Rațiu, 2008; Ionescu, 2009; Misachevici, 2011; Lung, 2018; Lung and Mureșan, 2018a; Lung and Mureșan, 2018b; Lung, 2019; Lung and Diaconescu, 2019). Population also aroused the interest of foreign researchers (Scharf, 2001; Findlay, 2003; Malmberg \& Tegenu, 2007; Finney \& Simpson, 2009; Stockdale, 2010; Keating et al., 2011; Sturtevant, 2013; Barakat, 2015). Historians have analyzed the population in terms of demographic history with connections to different political and administrative causes (Muntean, 2001; Pădurean, 2001; Holom, 2009; Ghiță, 2011). Sociological studies on the population were concerned with the human communities as a whole (Buțiu, 2004; Radu, 2014).

\section{METHODOLOGY}

In a first stage, we delineated the Eastern Carpathians from a geomorphological point of view, using the specialized bibliography (Posea \& Badea, 1984). To identify the cities that could be included in the studied area, we examined the specialized literature that has the Eastern Carpathians as a research topic (Ciangă, 1998; Popa-Bota, 2003; Niță, 2007; Mara, 2014; Tofan, 2012). After identifying the cities, a map with their geographical position was made. We used ArcGIS 10.1 to build the map. In the next stage, statistical data on population natural dynamics were obtained. These data were taken from the National Institute of Statistics website. Based on numerical data, we calculated the values of the three demographic indicators (birth rate, mortality rate and the rate of natural increase) for each census year after the communist period. In addition to the tables produced, graphs were created regarding the evolution of the number of newborns and deaths for the period 1992-2011. Before studying the natural dynamics, the demographic evolution of urban areas was briefly analyzed. For this, we considered a period beginning with the end of the $19^{\text {th }}$ century, continuing with the $20^{\text {th }}$ century and the beginning of the $21^{\text {st }}$ century. Numerical data from seven population censuses were used. 


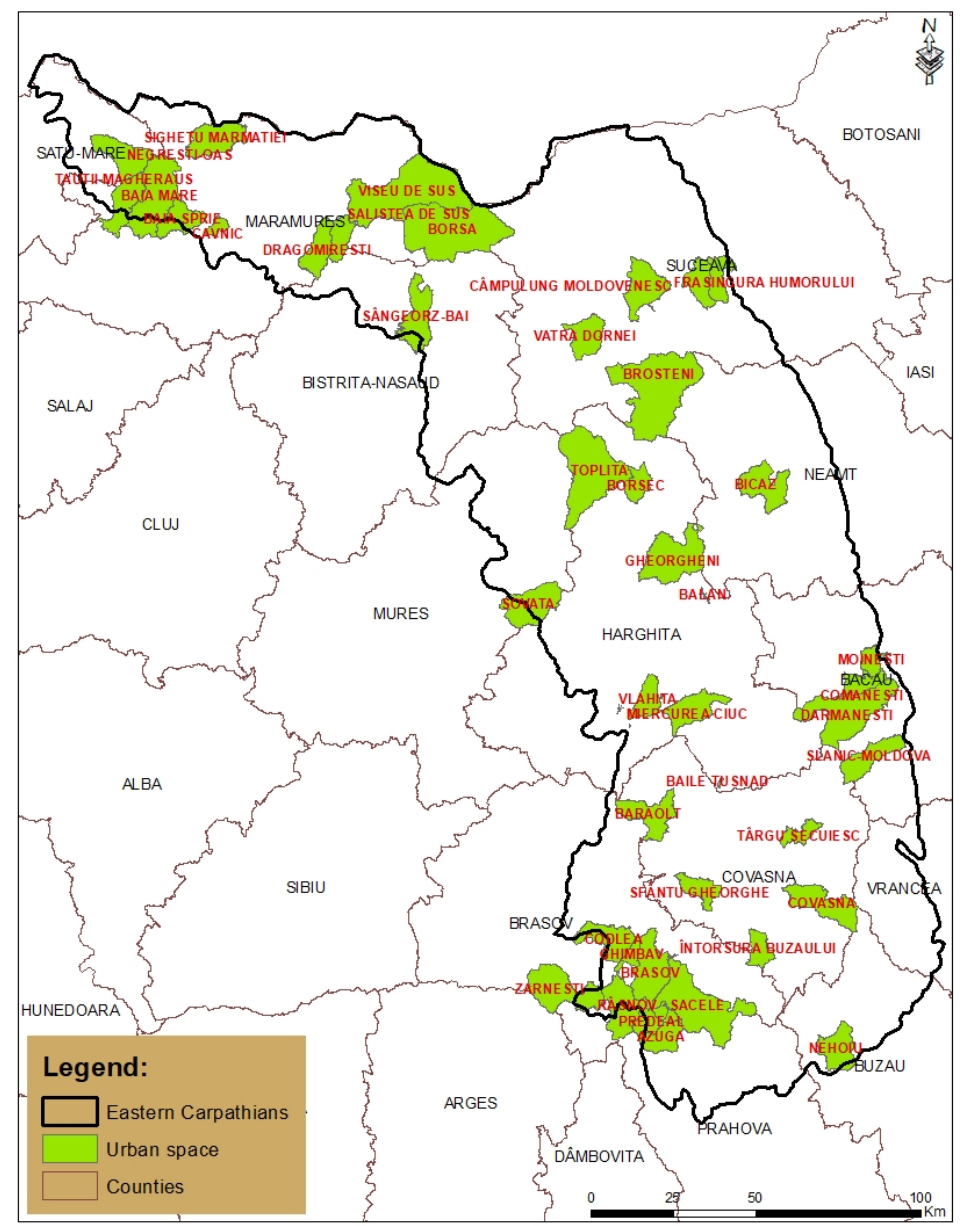

Figure 1. Cities in the Eastern Carpathians (source: own study)

\section{RESULTS}

\subsection{Demographic evolution}

Between 1880 and 1992, the rate of natural increase was permanently positive. During the analyzed period, the smallest number of the inhabitants in the 43 cities was recorded in 1880 . At the end of the $19^{\text {th }}$ century, the population of the cities was 166,702 inhabitants (fig. 2). At the end of the interwar period, the population increased to 338,722 inhabitants, 172,020 people more compared to 
1880. But the most significant demographic increase occurred during the communist period. In 1966, the population in the urban areas was 609,489 inhabitants, and after 1989 it exceeded 1 million inhabitants. In the 26 years from 1966 to 1992, the urban population in the Eastern Carpathians increased by 542,608 inhabitants. This was the largest urban demographic increase. In support of this phenomenon specific to the communist period was the law prohibiting abortion (Decree No. 770 of October 1, 1966), but also the intensification of industrial activities. The forced industrialization required by the leadership of the country forced the construction of numerous industrial factories in cities. These factories required a large workforce. Since 1992, the urban population has begun to decline, in 2011 numbering 1,114,966 people. Urban demographic decline can be attributed to industrial restructuring and layoffs among employees. After 1989 , most urban factories were closed or privatized, leading to a change in their organizational structure. Due to the lack of jobs, the population was forced to move to other regions and even to migrate abroad.

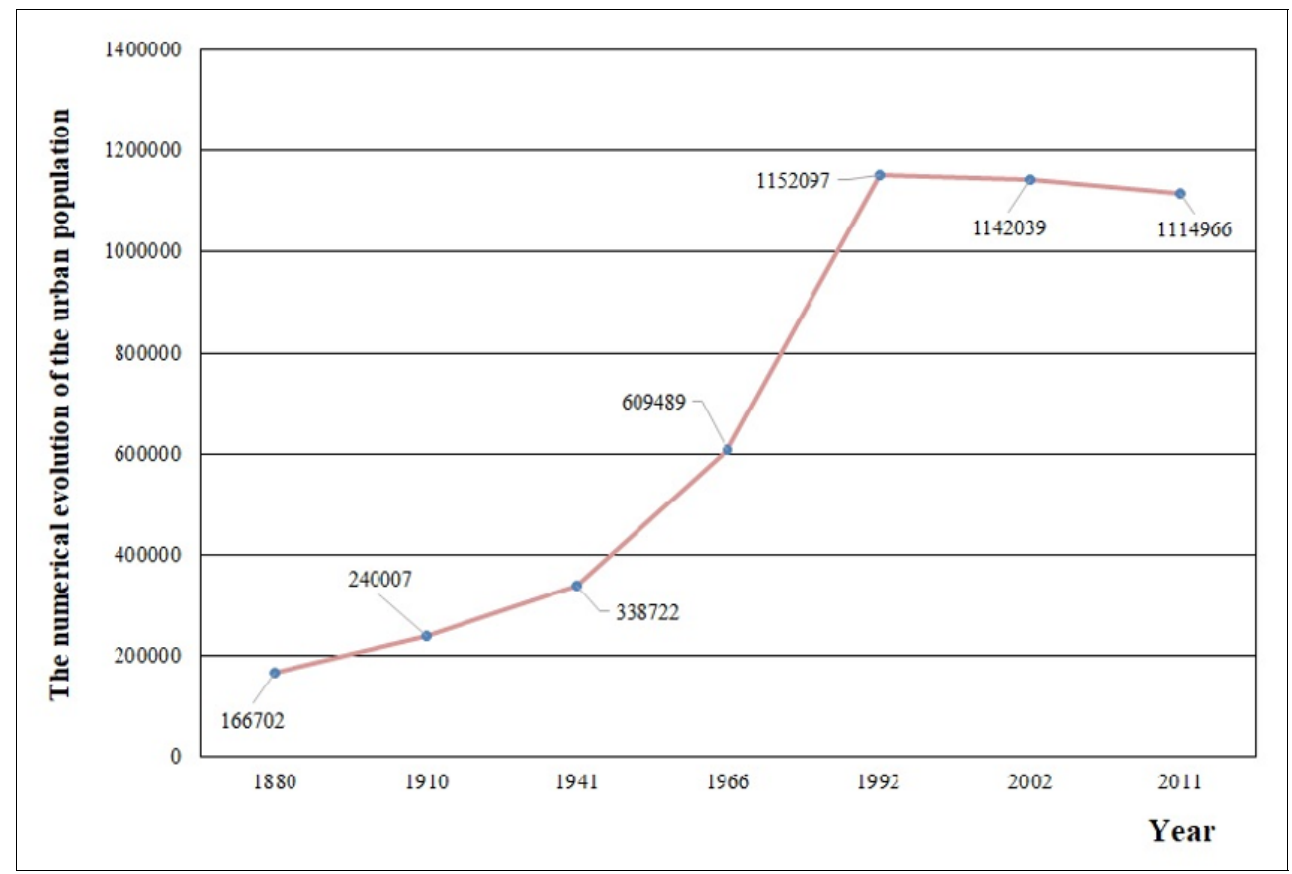

Figure 2. The numerical evolution of the urban population (Source: own calculation based on data from NIS and http://www.varga.adatbank.transindex.ro/) 


\subsection{Birth rate evolution}

At the first post-communist census (1992), the highest birth rate was 18.7 \%o in Sângeorz-Băi, Bistriţa-Năsăud County, at the opposite side being Ghimbav with $5.9 \%$ (see Table 1). Of the 43 cities, only eight had birth rates below $10 \%$, 28 registering values between 10.1-15\%o and 7 between 15.1-20\%o. Apart from Ghimbav, the seven cities with birth rates below $10 \%$ were: TăuţiiMăgherăuș 9.6 \%o, Borsec 8.7 \%o, Miercurea-Ciuc 9.6 \%o, Sfântu Gheorghe 9.7 \%o, Braşov $8.2 \%$ and Predeal $7.6 \%$. The highest rates, except for Sângeorz-Băi, were in: Dragomirești 15.3 \%o, Borșa 17.5 \%o, Broșteni 15.2 \%o, Bălan 15.3 \%o, Comăneşti 16.1 \%o, Dărmăneşti 17.0 \%o. The year 1992 was characterized by the highest birth rates of the entire study period. Until the first census of the $21^{\text {st }}$ century (2002), the birth rate registered a noticeable decline. In 2002, Sângeorz-Băi also had the highest value, but it decreased considerably to 14.0 $\%$; the lowest birth rate was recorded in Azuga, $6.0 \%$. The number of cities with birth rates values below $10 \%$ increased significantly compared to 1992 . At the 2002 census, 29 cities had birth rates below $10 \%$ and none exceeded $15.1 \%$ o. Until 2011, the birth rate in the urban area decreased more than in 2002. In 2011, problems worsened, with only five cities having birth rates between 10.1-15\%o (Borșa 11.7\%o, Sângeorz-Băi 13.9 \%o, Vlăhița 11.1 \%o, Dărmănești 10.9 \%o, Slănic Moldova 10.4 \%o) and only one over 15.1 \%o (Săcele 15.6 \%o). In 2011 , the birth rate situation was so acute that two cities with a birth rate of less than 5 \%o were registered: Bicaz 4.0 \%o, and Săliștea de Sus 3.9 \%o.

Table 1. Birth rates at post-communist censuses

(source: own calculation based on data from NIS)

\begin{tabular}{|c|c|c|c|c|}
\hline \multirow{2}{*}{ No. } & \multirow{2}{*}{ City } & \multicolumn{3}{|c|}{ Year } \\
\cline { 3 - 5 } & & $\mathbf{1 9 9 2}$ & $\mathbf{2 0 0 2}$ & $\mathbf{2 0 1 1}$ \\
\hline 1. & Negrești-Oaș & 14.4 & 7.0 & 5.9 \\
\hline 2. & Baia Mare & 13.2 & 9.0 & 8.8 \\
\hline 3. & Tăuții-Măgherăuș & 9.6 & 7.2 & 9.6 \\
\hline 4. & Baia Sprie & 13.5 & 9.7 & 8.3 \\
\hline 5. & Cavnic & 13.3 & 8.9 & 8.8 \\
\hline 6. & Sighetu Marmației & 12.6 & 9.4 & 8.8 \\
\hline 7. & Dragomirești & 15.3 & 8.6 & 7.3 \\
\hline 8. & Săliștea de Sus & 12.7 & 8.5 & 3.9 \\
\hline 9. & Vișeu de Sus & 14.8 & 10.4 & 8.0 \\
\hline 10. & Borșa & 17.5 & 8.2 & 11.7 \\
\hline
\end{tabular}


MĂDĂLIN-SEBASTIAN LUNG, GABRIELA-ALINA MUREȘAN

\begin{tabular}{|c|c|c|c|c|}
\hline \multirow{2}{*}{ No. } & \multirow{2}{*}{ City } & \multicolumn{3}{|c|}{ Year } \\
\hline & & 1992 & 2002 & 2011 \\
\hline 11. & Sângeorz-Băi & 18.7 & 14.0 & 13.9 \\
\hline 12. & Câmpulung Moldovenesc & 11.0 & 9.8 & 6.6 \\
\hline 13. & Frasin & 11.1 & 11.2 & 9.1 \\
\hline 14. & Gura Humorului & 10.7 & 8.7 & 9.3 \\
\hline 15. & Vatra Dornei & 11.6 & 7.4 & 7.8 \\
\hline 16. & Broșteni & 15.2 & 8.6 & 7.7 \\
\hline 17. & Toplița & 13.1 & 10.3 & 6.5 \\
\hline 18. & Borsec & 8.7 & 8.5 & 9.9 \\
\hline 19. & Bicaz & 13.8 & 10.1 & 4.0 \\
\hline 20. & Gheorgheni & 10.9 & 8.1 & 7.9 \\
\hline 21. & Sovata & 12.7 & 10.7 & 6.9 \\
\hline 22. & Bălan & 15.3 & 10.7 & 6.5 \\
\hline 23. & Vlăhița & 12.5 & 9.3 & 11.1 \\
\hline 24. & Miercurea Ciuc & 9.6 & 8.7 & 9.3 \\
\hline 25. & Moinești & 14.3 & 8.4 & 8.1 \\
\hline 26. & Comănești & 16.1 & 9.3 & 8.0 \\
\hline 27. & Dărmănești & 17.0 & 11.0 & 10.9 \\
\hline 28. & Slănic Moldova & 14.6 & 11.8 & 10.4 \\
\hline 29. & Băile Tușnad & 12.6 & 10.5 & 6.4 \\
\hline 30. & Târgu Secuiesc & 10.6 & 8.5 & 6.8 \\
\hline 31. & Baraolt & 11.2 & 10.8 & 8.1 \\
\hline 32. & Sfântu Gheorghe & 9.7 & 8.2 & 8.3 \\
\hline 33. & Covasna & 11.4 & 7.5 & 7.2 \\
\hline 34. & Întorsura Buzăului & 12.6 & 12.7 & 9.3 \\
\hline 35. & Codlea & 10.0 & 10.9 & 9.8 \\
\hline 36. & Ghimbav & 5.9 & 6.6 & 5.9 \\
\hline 37. & Brașov & 8.2 & 6.4 & 7.9 \\
\hline 38. & Săcele & 10.2 & 12.3 & 15.6 \\
\hline 39. & Zărnești & 12.5 & 9.2 & 8.6 \\
\hline 40. & Râșnov & 9.0 & 9.3 & 8.1 \\
\hline 41. & Predeal & 7.6 & 9.4 & 7.5 \\
\hline 42. & Azuga & 10.7 & 6.0 & 6.1 \\
\hline 43. & Nehoiu & 11.4 & 7.3 & 5.6 \\
\hline
\end{tabular}


Regarding the evolution of newborns in the urban area of the Eastern Carpathians, we can see that the maximum number was registered in 1992 (12,913 newborns), after which it decreased continuously until 1996 (fig. 3). Between 1996 and 2011 there were alternative periods of increase and decline, but in 2011 the lowest number of newborns in the entire period analyzed was registered, only 9,578. The total number of newborns remained at over 10,000, except for 2002, 2003 and 2011. Newborns evolution is closely linked to the young population, who in the post-communist period migrated in search of jobs and a higher standard of living. Only a few returned, leaving behind, in the cities, the aging population.

The share of the different birth rates has distinctive values from one census to another. In 1992, the highest share, $65 \%$, was assigned to values of 10.1-15\%o (28 cities), followed by values below $10 \%$ (19\%) and 15.1-20\%o with $16 \%$. In 2002, most values were below $10 \%$, totaling 67\% (29 cities) and 33\% represented values between 10.1-15\%o. No value greater than $15.1 \%$ was recorded in that year, being a singular case for the entire time interval analyzed. At the last census (2011), the birth rate situation in the Eastern Carpathians was completely different. With a significant majority of $86 \%$, the values below $10 \%$ were the most numerous (37 cities), following the rates between $10.1-15 \%$ with $12 \%$ and those higher than $15.1 \%$ with only $2 \%$ (1 city). Between 1992 and 2011, the birth rate dynamics was constantly changing, with short periods of increase and others of decline.

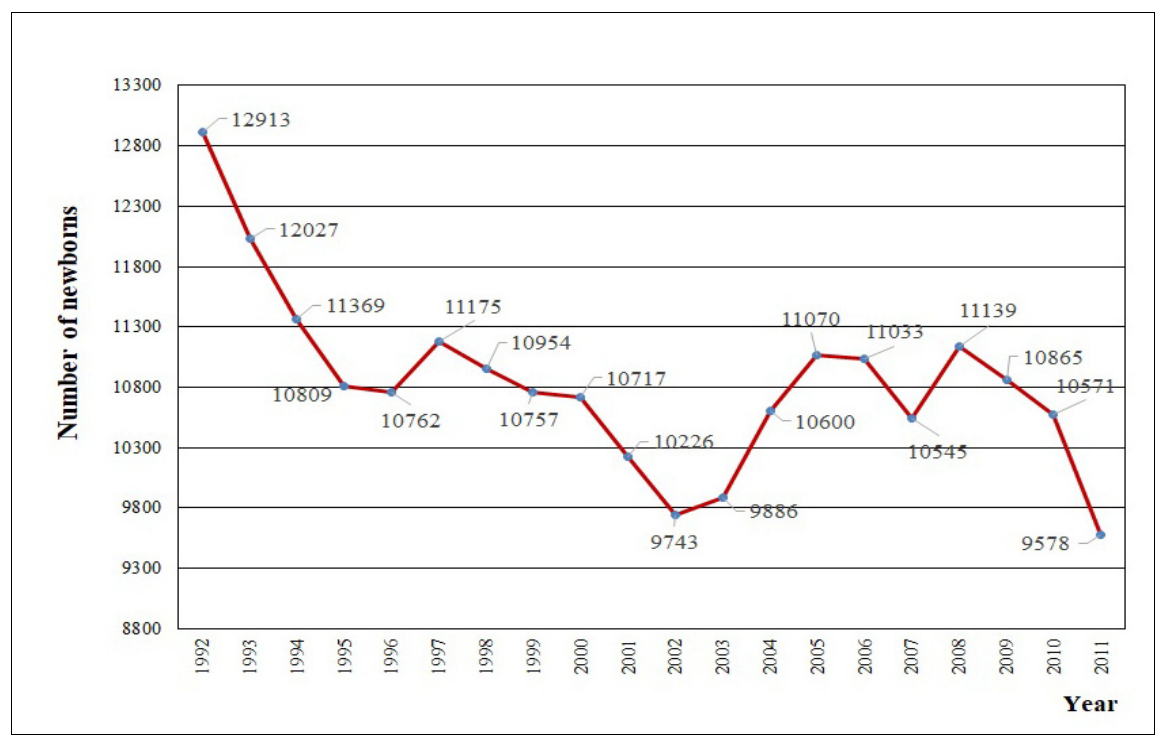

Figure 3. Numerical evolution of newborns between 1992 and 2011 (Source: own calculation based on data from NIS) 


\subsection{Mortality rate evolution}

The second demographic indicator under study was the mortality rate. Outputs from the system (mortality), together with the young population migration, can lead to demographic risk phenomena. In 1992, the biggest problems regarding the mortality rate were in Tăuții-Măgherăuș (16.3 \%o) and Dragomirești (16.2 \%o) (see Table 2). They are the only two values over $15 \%$ o. Of the 43 cities, 28 recorded mortality rates below $10 \%$. It can be seen that in 1992 there are no major dysfunctions regarding mortality rates. In 2002, the number of values below $10 \%$ decreased to 25 , which shows an increase in mortality. Cities with a mortality rate of more than 10 \%o compared to 1992 are: Bicaz, Dărmănești, Slănic Moldova, Covasna, Săcele and Predeal. A number of 17 administrative units recorded rates between 10.1-15 \%o at the 2002 census and one above $15.1 \%$ (ȚăuțiiMăgherăuș, with 15.5 \%o). In 2011, the mortality rate showed a downward trend, 27 cities having values below $10 \%$. The number of urban settlements with rates between 10.1-15\%o decreased from 2002 to 14 . Two cities exceeded $15.1 \%$ : Nehoiu $15.0 \%$ and Borsec $15.2 \%$ (the highest value). In general, mortality rates are higher than birth rates, which is evidenced by the negative values of the natural increase rate.

Table 2. Mortality rates at post-communist censuses (source: own calculation based on data from NIS)

\begin{tabular}{|c|c|c|c|c|}
\hline \multirow{2}{*}{ No. } & \multirow{2}{*}{ City } & \multicolumn{3}{|c|}{ Year } \\
\cline { 3 - 5 } & & $\mathbf{1 9 9 2}$ & $\mathbf{2 0 0 2}$ & $\mathbf{2 0 1 1}$ \\
\hline 1. & Negrești-Oaș & 8.7 & 9.5 & 7.2 \\
\hline 2. & Baia Mare & 8.2 & 7.8 & 7.7 \\
\hline 3. & Tăuții-Măgherăuș & 16.3 & 15.5 & 10.1 \\
\hline 4. & Baia Sprie & 10.0 & 11.4 & 10.5 \\
\hline 5. & Cavnic & 11.2 & 11.2 & 9.3 \\
\hline 6. & Sighetu Marmației & 10.7 & 9.8 & 8.9 \\
\hline 7. & Dragomirești & 16.2 & 11.0 & 9.4 \\
\hline 8. & Săliștea de Sus & 11.8 & 10.8 & 11.2 \\
\hline 9. & Vișeu de Sus & 9.5 & 9.4 & 9.0 \\
\hline 10. & Borșa & 8.1 & 7.8 & 6.6 \\
\hline 11. & Sângeorz-Băi & 8.0 & 7.3 & 6.8 \\
\hline 12. & Câmpulung Moldovenesc & 10.4 & 11.6 & 11.0 \\
\hline 13. & Frasin & 10.8 & 11.8 & 11.1 \\
\hline 14. & Gura Humorului & 9.0 & 8.0 & 9.2 \\
\hline 15. & Vatra Dornei & 9.9 & 9.7 & 10.4 \\
\hline 16. & Broșteni & 10.1 & 9.1 & 11.9 \\
\hline 17. & Toplița & 8.9 & 8.1 & 8.6 \\
\hline
\end{tabular}


NATURAL DYNAMICS OF URBAN POPULATION IN THE EASTERN CARPATHIANS ...

\begin{tabular}{|c|c|c|c|c|}
\hline \multirow[b]{2}{*}{ No. } & \multirow{2}{*}{ City } & \multicolumn{3}{|c|}{ Year } \\
\hline & & 1992 & 2002 & 2011 \\
\hline 18. & Borsec & 12.0 & 10.9 & 15.2 \\
\hline 19. & Bicaz & 8.3 & 11.5 & 8.7 \\
\hline 20. & Gheorgheni & 10.1 & 10.3 & 9.3 \\
\hline 21. & Sovata & 11.4 & 10.7 & 9.5 \\
\hline 22. & Bălan & 4.5 & 4.1 & 6.9 \\
\hline 23. & Vlăhița & 9.5 & 9.7 & 8.8 \\
\hline 24. & Miercurea Ciuc & 6.1 & 7.5 & 7.5 \\
\hline 25. & Moinești & 9.0 & 9.7 & 10.3 \\
\hline 26. & Comănești & 8.2 & 8.5 & 10.4 \\
\hline 27. & Dărmănești & 9.0 & 13.3 & 11.6 \\
\hline 28. & Slănic Moldova & 8.5 & 10.1 & 9.8 \\
\hline 29. & Băile Tușnad & 12.1 & 8.4 & 11.6 \\
\hline 30. & Târgu Secuiesc & 9.0 & 8.0 & 7.8 \\
\hline 31. & Baraolt & 12.0 & 12.7 & 12.8 \\
\hline 32. & Sfântu Gheorghe & 7.0 & 7.6 & 7.5 \\
\hline 33. & Covasna & 9.2 & 10.7 & 9.7 \\
\hline 34. & Întorsura Buzăului & 7.7 & 8.8 & 8.0 \\
\hline 35. & Codlea & 5.7 & 6.2 & 7.2 \\
\hline 36. & Ghimbav & 5.0 & 8.0 & 5.4 \\
\hline 37. & Brașov & 7.2 & 8.9 & 8.8 \\
\hline 38. & Săcele & 9.4 & 10.5 & 7.5 \\
\hline 39. & Zărnești & 8.5 & 8.9 & 8.6 \\
\hline 40. & Râșnov & 7.0 & 7.8 & 7.0 \\
\hline 41. & Predeal & 7.5 & 11.4 & 12.7 \\
\hline 42. & Azuga & 9.1 & 9.0 & 11.6 \\
\hline 43. & Nehoiu & 10.8 & 12.2 & 15.0 \\
\hline
\end{tabular}

The chart on the evolution of the number of deaths in the urban areas of the Eastern Carpathians shows periods of increase and decrease more evident than the graph of newborns evolution (fig. 4). The ascending and descending progression of deaths has a longer period of time than newborns. The lowest number of deaths was recorded in 1993 (9,553). Three successive years with an increase in the number of deaths followed until 1996, when 10,204 deaths were recorded. Since 1997 there have been three years with a decrease in the number of deaths; in 2000 there were 9,670 deaths. The peak was recorded in 2002 when 10,260 people died.

Mortality rates are more homogeneous than birth rates. In 1992, values below $10 \%$ prevailed, with $65 \%$ of the total (28 cities), followed by those between 10.1-15\%o with 30\% and those higher than $15.1 \%$ o (5\%). At 
the next census, the share of rates below $10 \%$ decreased to $58 \%$ ( 25 cities), the rates between $10.1-15 \%$ increased to $40 \%$ (17 cities), and those exceeding $15.1 \%$ decreased to $2 \%$. In 2011, the majority of $63 \%$ (27 cities) belonged to values below $10 \%$, increasing compared to 2002 . The share of rates between 10.1-15\%o decreased to $32 \%$ compared to 2002, and the share of those who exceeded $15 \%$ increased to 5\% (2 cities). During the study period, the most frequently recorded values were below $10 \%$.

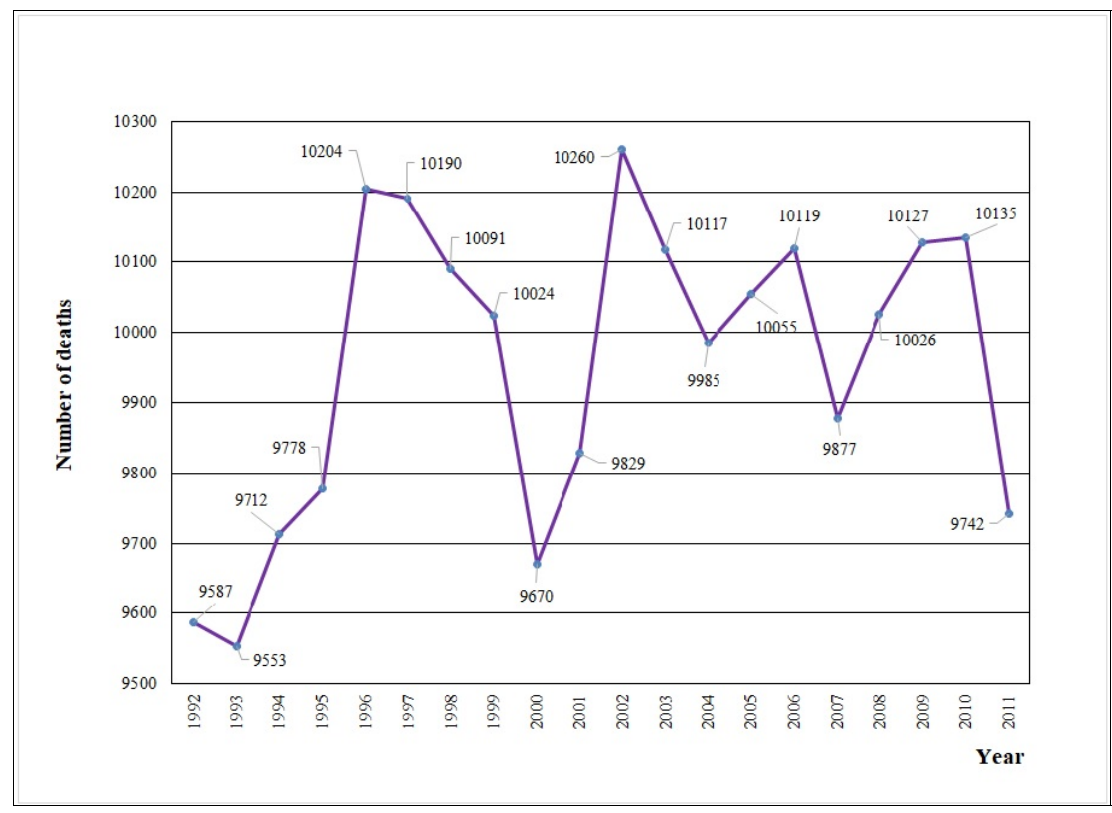

Figure 4. Numerical evolution of deaths between 1992 and 2011 (Source: own calculation based on data from NIS)

\subsection{Evolution of the rate of natural increase}

In 1992, out of the 43 cities, only four had negative natural dynamics (i.e. a natural decrease) (Tăuții-Măgherăuș -6.7 \%o, Dragomirești $-0.8 \%$ o, Borsec -3.2 \%o, Baraolt $-0.7 \%$ ). Two cities had natural increase values greater than $10 \%$ (Sângeorz-Băi 10.7 \%o and Bălan 10.7 \%o). Most values ranged from 0 to 5 \%o in 28 cities. In 2002, natural increase rates changed to a large extent, with no less than 24 negative values being recorded. The lowest value was $-8.2 \%$ in TăuțiiMăgherăuș. The number of cities with values between 0 and $5 \%$ decreased to 16, 12 less than in 1992. A value of $0 \%$ was recorded in Sovata, being the only 
one in the whole analyzed period. As in 1992, the maximum value was registered in the city of Sângeorz-Băi, but it was much lower, $6.6 \%$. At the 2011 census, the demographic situation of the urban areas in the Eastern Carpathians worsened. No less than 29 cities had negative values of the natural increase. The lowest rate was recorded in Nehoiu, and the highest in Sângeorz-Băi, -9.3 \%o and $7.1 \%$, respectively. During the whole period, Sângeorz-Băi has preserved the highest values of the natural increase, imposing itself on every census. Since 1992, natural increase rates have been steadily decreasing. Based on the results, we can say that the urban areas in the Eastern Carpathians face demographic risk phenomena. The lack of jobs led to the migration of the young population, so that the older population remained in most cities. Youth migration is the main demographic risk that cities face in the post-communist period. We find that the migration dynamics has consequences on the population natural dynamics.

Table 3. Rates of natural dynamics in the census years (source: own calculation based on data from NIS)

\begin{tabular}{|c|c|c|c|c|}
\hline \multirow{2}{*}{ No. } & \multirow{2}{*}{ City } & \multicolumn{3}{|c|}{ Year } \\
\cline { 2 - 5 } & Negrești-Oaș & $\mathbf{1 9 9 2}$ & $\mathbf{2 0 0 2}$ & $\mathbf{2 0 1 1}$ \\
\hline 1. & Baia Mare & 5.7 & -2.4 & -1.2 \\
\hline 2. & Tăuții-Măgherăuș & -6.7 & -8.2 & 1.1 \\
\hline 3. & Baia Sprie & 3.4 & -1.6 & -0.5 \\
\hline 4. & Cavnic & 2.0 & -2.2 & -2.2 \\
\hline 5. & Sighetu Marmației & 1.8 & -0.4 & -0.0 \\
\hline 6. & Dragomirești & -0.8 & -2.3 & -2.1 \\
\hline 7. & Săliștea de Sus & 0.8 & -2.3 & -7.2 \\
\hline 8. & Vișeu de Sus & 5.2 & 1.0 & -0.9 \\
\hline 9. & Borșa & 9.4 & 0.4 & 5.0 \\
\hline 10. & Sângeorz-Băi & 10.7 & 6.6 & 7.1 \\
\hline 11. & Câmpulung Moldovenesc & 0.5 & -1.7 & -4.3 \\
\hline 12. & Frasin & 0.3 & -0.6 & -2.0 \\
\hline 13. & Gura Humorului & 1.6 & 0.7 & 0.1 \\
\hline 14. & Vatra Dornei & 1.6 & -2.2 & -2.6 \\
\hline 15. & Broșteni & 5.0 & -0.4 & -4.1 \\
\hline 16. & Toplița & 4.1 & 2.2 & -2.0 \\
\hline 17. & Borsec & -3.2 & -2.4 & -5.3 \\
\hline 18. & Bicaz & 5.4 & -1.4 & -4.6 \\
\hline 19. & Gheorgheni & 0.7 & -2.2 & -1.4 \\
\hline 20. & Sovata & 1.2 & 0 & -2.6 \\
\hline 21. & Bălan & 10.7 & 6.5 & -0.3 \\
\hline 22. & Vlăhița & 3.0 & -0.3 & 2.3 \\
\hline 23. & & & & \\
\hline
\end{tabular}




\begin{tabular}{|c|c|c|c|c|}
\hline \multirow{2}{*}{ No. } & \multirow{2}{*}{ City } & \multicolumn{3}{|c|}{ Year } \\
\cline { 3 - 5 } & & $\mathbf{1 9 9 2}$ & $\mathbf{2 0 0 2}$ & $\mathbf{2 0 1 1}$ \\
\hline 24. & Miercurea Ciuc & 3.5 & 1.1 & 1.8 \\
\hline 25. & Moinești & 5.2 & -1.3 & -2.1 \\
\hline 26. & Comănești & 7.9 & 0.8 & -2.4 \\
\hline 27. & Dărmănști & 8.0 & -2.3 & -0.6 \\
\hline 28. & Slănic Moldova & 6.0 & 1.6 & 0.5 \\
\hline 29. & Băile Tușnad & 0.5 & 2.1 & -5.2 \\
\hline 30. & Târgu Secuiesc & 1.5 & 0.5 & -1.0 \\
\hline 31. & Baraolt & -0.7 & -1.8 & -4.6 \\
\hline 32. & Sfântu Gheorghe & 2.6 & 0.6 & 0.8 \\
\hline 33. & Covasna & 2.1 & -3.2 & -2.4 \\
\hline 34. & Întorsura Buzăului & 4.8 & 3.8 & 1.2 \\
\hline 35. & Codlea & 4.2 & 4.6 & 2.5 \\
\hline 36. & Ghimbav & 0.9 & -1.3 & 0.5 \\
\hline 37. & Brașov & 0.9 & -2.4 & -0.8 \\
\hline 38. & Săcele & 0.7 & 1.8 & 8.0 \\
\hline 39. & Zărnești & 3.9 & 0.3 & 0 \\
\hline 40. & Râșnov & 2.0 & 1.4 & 1.1 \\
\hline 41. & Predeal & 0.1 & -1.9 & -5.1 \\
\hline 42. & Azuga & 1.6 & -2.9 & -5.5 \\
\hline 43. & Nehoiu & 0.6 & -4.8 & -9.3 \\
\hline
\end{tabular}

\section{Conclusions}

The period 1992-2011 was one that caused important changes in the natural dynamics of the population in the 43 cities located in the Eastern Carpathians. In 1992 most cities had a higher birth rate than mortality rate, but values have changed in the meantime. Since the beginning of the $21^{\text {st }}$ century, mortality rates have started to rise, exceeding birth rates. These trends were registered in all urban areas, the number of negative values of the natural increase rate being, in 2002, higher than in 1992. If, in 1992, Bălan and Sângeorz-Băi had the highest value of the natural increase, over $10 \%$, in 2002 they reached only $6.5 \%$ and $6.6 \%$ respectively. In 2011, the urban areas faced the most important demographic dysfunctions, registering the largest number of negative values in terms of natural increase rate. Among the most worrying demographic phenomena we can mention the migration of young population. The low number and low paid jobs force the young workforce to leave the cities. Young people are the main pillar of positive natural dynamics, and in their absence, the aging population can hardly sustain itself. 


\section{REFERENCES}

1. Barakat, B. (2015). A 'recipe for depopulation'? School closures and local population decline in Saxony. Population, Space and Place, 21(8), 735-753.

2. Buţiu, C-A. (2004). Sărăcia comunităţilor urbane din Munţii Apuseni (Poverty of urban communities in the Apuseni Mountains) [PhD thesis]. Universitatea „BabeșBolyai", Facultatea de Sociologie şi Asistenţă Socială, Cluj-Napoca.

3. Ciangă, N. (1998). Turismul din Carpaţii Orientali: studiu de geografie umană (Tourism in the Eastern Carpathians: A Human Geography study), Edit. Presa Universitară Clujeană, Cluj-Napoca.

4. Findlay, A.M. (2003). Population geographies for the 21st century. Scottish Geographical Journal, 119(3), 177-190.

5. Finney, N., Simpson, L. (2009). Population dynamics: The roles of natural change and migration in producing the ethnic mosaic. Journal of Ethnic and Migration Studies, 35(9), 1479-1496.

6. Ghiţă, E-C. (2011). Evoluţia demografică a comitatului Arad în secolul al XVIII-lea şi la începutul secolului al XIX-lea (The demographic evolution of Arad County in the eighteenth and early nineteenth centuries), Edit. Presa Universitară Clujeană, Cluj-Napoca.

7. Giurcăneanu, C. (1988). Populaţia şi asezările din Carpaţii românești (Population and settlements in the Romanian Carpathians), Edit. Ştiinţifică şi Enciclopedică, București.

8. Holom, E-C. (2009). Evoluţia demografică şi problema familiei în actualul județ Alba (1850-1910) (The demographic evolution and the family problem in the present Alba county [1850-1910]). [PhD thesis]. Universitatea „Babeș-Bolyai”, Facultatea de Istorie şi Filosofie, Cluj-Napoca.

9. Ionescu, N-D. (2009). Populaţia și aşezările din Dealurile Someșului Mare (Population and settlements in Someşului Mare Hills), [PhD thesis]. Universitatea „Babeș-Bolyai”, Facultatea de Geografie, Cluj-Napoca.

10. Keating, N., Swindle, J., Fletcher, S. (2011). Aging in rural Canada: A retrospective and review. Canadian Journal on Aging, 30(3), 323-338.

11. Lung, M-S. (2019), Continuity and Demographic Cycling in the Romanian Carpathian Space in the Period 1930-2011, Analele Universității din Oradea, Seria Geografie, 29(1), 79-91. https://doi.org/10.30892/auog.291109-802

12. Lung, M-S., Diaconescu, L. (2019), Altitudinal Distribution of Population and Settlements in the Carpathian Mountain Space. Case Study: Romanian Carpathians, Revista Română de Geografie Politică, 21(1), 1-17. https://doi.org/10.30892/rrgp.211101-324

13. Lung, M-S. (2018), The natural dynamics of the rural population in Apuseni Mountains (2011 Census), Revista Romană de Geografie Politică, 20(2): 41-48.

14. Lung, M-S., Mureșan, G-A. (2018a), Caracteristici demografice ale orașelor mici din județul Caraș-Severin în perioada postcomunistă (Demographic characteristics of small towns in Caraș-Severin county during the post-communist period), Geographia Napocensis, XII (1): 7-15.

15. Lung, M-S., Mureșan, G-A. (2018b), Dinamica naturală a populației din depresiunile intramontane ale Carpaților Orientali (The population natural dynamics from the intramontane depressions of the Eastern Carpathians), Geographia Napocensis, XII (2): 25-32. 
16. Malmberg, B., Tegenu, T. (2007). Population pressure and dynamics of household livelihoods in an Ethiopian Village: an elaboration of the Boserup-Chayanovian framework. Population and Environment, 29: 39-67.

17. Mara, V. (2014). Giurgeu şi Ciuc: studiu de geografie regională (Giurgeu and Ciuc: a Study of Regional Geography), Edit. Presa Universitară Clujeană, Cluj-Napoca.

18. Misachevici, A. (2011). Populația și așezările din Depresiunea Sibiului (Population and settlements in Sibiu Depression), [PhD thesis]. Universitatea „Babeș-Bolyai”, Facultatea de Geografie, Cluj-Napoca.

19. Muntean, A-F. (2001). Evoluţia demografică a comitatelor Bihor, Maramureș și Satu Mare intre 1850-1918 (Demographic evolution of Bihor, Maramureş and Satu Mare counties between 1850-1918), [PhD thesis]. Universitatea „Babeș-Bolyai”, Facultatea de Istorie şi Filosofie, Cluj-Napoca.

20. Niță, A-F. (2007). Populaţia şi aşezările din Depresiunea Braşov (Population and settlements in Sibiu Depression0, [PhD thesis]. Universitatea „Babeș-Bolyai”, Facultatea de Geografie, Cluj-Napoca.

21. Pădurean, C. (2001). Evoluţia demografică a judeţului Arad în secolul al XIX-lea (Arad County demographic evolution in the 19th century), [PhD thesis]. Universitatea „Babeș-Bolyai”, Facultatea de Istorie şi Filosofie, Cluj-Napoca.

22. Popa-Bota, H. (2003). Organizarea spaţiului geografic în Depresiunea Maramureșului (Geographical space organization in the Maramures Depression) [PhD thesis]. Universitatea „Babeș-Bolyai”, Facultatea de Geografie, Cluj-Napoca.

23. Posea, G., Badea, L. (1984). România. Unitătile de relief (Regionarea geomorfologică), Edit. Științifică și Enciclopedică, București.

24. Radu, B-V. (2014). Rezilienţa fostelor comunităţi miniere (The resilience of former mining communities), [PhD thesis]. Universitatea „Babeș-Bolyai”, Facultatea de Sociologie şi Asistență Socială, Cluj-Napoca.

25. Raţiu, R-F. (2008). Populaţia şi aşezările din Câmpia Someșană (Câmpia Transilvaniei) (Population and settlements of Someşană Plain (Transylvania Plain), Edit. Casa Cărţii de Știință, Cluj-Napoca.

26. Scharf, T. (2001). Ageing and intergenerational relationships in rural Germany. Ageing \& Society, 21(5), 547-566.

27. Stockdale, A. (2010). The diverse geographies of rural gentrification in Scotland. Journal of Rural Studies, 26(1), 31-40.

28. Sturtevant, L. (2013). The new District of Columbia: What population growth and demographic change mean for the city, Journal of Urban Affairs, 36, 2, (276-299).

29. Tănasă, E. (2007). Populaţia şi aşezările din Câmpia Mureşană (Câmpia Transilvaniei) (Population and settlements of Mureşană Plain (Transylvania Plain), [PhD thesis]. Universitatea „Babeș-Bolyai”, Facultatea de Geografie Cluj-Napoca.

30. Tofan, G-B. (2012). Depresiunile mici, factori și componentă a umanizării (antropizării) Grupei Centrale a Carpaţilor Orientali: studiu de caz: componenta nordică a ulucului depresionar (Drăgoiasa-Glodu-Bilbor-Secu-Borsec-Corbu-Tulgheş), [PhD thesis]. Universitatea „Babeș-Bolyai”, Facultatea de Geografie, Cluj-Napoca.

31. ${ }^{* * *}$ Decree No. 770 of 1 October 1966, retrieved from http://www.legex.ro/Decretul-770-1966-363.aspx, last accessed on 16 July 2018.

32. *** http://www.varga.adatbank.transindex.ro/, last accessed on 16 July 2018.

33. ${ }^{* * *}$ National Institute of Statistics, Tempo-Online, www.insse.ro, last accessed on 15 July 2018. 